\title{
Rapid Assessment of the State of Economic and Financial Security of the Ukrainian Defense Enterprises in Conditions of Interaction with Business Environment
}

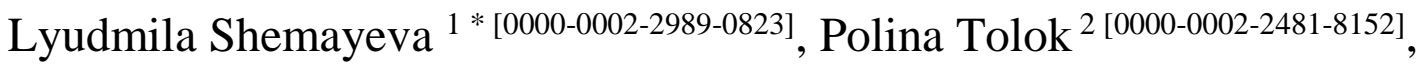 \\ Yurii Ivanov 1 [0000-0003-4901-5337] \\ ${ }^{I}$ National Academy of Security Service of Ukraine, Kyiv, Ukraine \\ ${ }^{2}$ Central Research Institute of the Armed Forces of Ukraine, Kyiv, Ukraine \\ *shemayeva@ukr.net
}

\begin{abstract}
In the context of expanding the range of interaction of defense companies with the market environment, it is important to improve approaches to assess their economic and financial security to identify importance, and impacting vectors of external factors, and propose timely response to their impact. There is a need to improve and implement integrated rating approaches to assess and increase their adequacy to modern market conditions, increase efficiency of that assessment and determine a number of indicators for its performance. With this in mind, the method and indicators of rapid assessment of the state of financial and economic security of defense enterprises are proposed. The rapid assessment results in the calculation of an integrated indicator of financial and economic security of an enterprise, which takes into account the indicators of interaction of the enterprise with the business environment, which indirectly reflects their impact. To interpret the results of the assessment of the integrated indicator, the mathematical distribution of the set of points in a quarter was used. The results of the rapid assessment of financial and economic security at 11 domestic defense companies has indicated improvement of their financial and economic security values with the beginning of the military conflict in the Eastern Ukraine and confirmed indirect impact of enterprises' active interaction with the external partners on their economic and financial security (by boosting exports-imports contracts, establishing partnerships with suppliers/consumers, government relations with the state, etc.).
\end{abstract}

Keywords: defense enterprises, economic and financial, rapid assessment, integrated indicator, active interaction.

\section{INTRODUCTION}

In modern conditions, the Ukraine's defense industry can be competitive if it can effectively adapt to changes in the market environment, timely take preventive measures against the effects of negative external factors $[1,2]$, which should be taken into account when forming a mechanism to assure economic and financial security (hereinafter refer to as EFS) of defense enterprises. In the context of expanding their range of interaction with the business environment [3], approaches to assess EFS of these enterprises need to be improved to identify the importance and directions of the influence of the external factors.

\section{RESEARCH METHODOLOGY}

Analysis of existing approaches to assess various conditions and aspects of EFS of defense enterprises has been performed, in particular: identification of typical problems in defense enterprises $[4,5]$ in the context of modern economic security [6], a systematic approach to strategy for the economic security of Ukraine's defense industry in the context of European integration [7], and in the context of forced remilitarization of its economy [8], economic and financial technologies at the enterprises [9-11] confirmed that there is an urgent need to improve and implement integrated rating approaches to such evaluation, taking into account the shortcomings of existing approaches and increase their adaptability to modern market trends by increasing efficiency of such assessment (rapid assessment) [12,13] and determining 
the list of EFS indicators. Given that, a rapid assessment of the current state of EFS of defense enterprises is proposed to be carried out according to the following method.

At the first stage, the indicators and their distribution according to the stages of rapid assessment (Figure 1) are determined using the following criteria: 1) ensuring the financial independence of enterprises (liquidity and solvency indicators), 2) efficiency of enterprises (profitability, profitability indicators), 3) business activity of enterprises, 4) the state of relations of enterprises with the subjects of the business environment.

\begin{tabular}{|c|l|l|l|l|}
\hline \multicolumn{5}{|c|}{ Indicators of rapid assessment of the condition of EFS of defense } \\
enterprises
\end{tabular}

Source: authors using [14, 15].

Figure 1 The system of indicators that characterize the state of EFS of defense enterprises in terms of interaction with the business environment

At the second stage, a rapid assessment of EFS of the enterprise is carried out, which results in an integrated indicator calculated based on 10 indicators that comprehensively reflect the state of liquidity and solvency, profitability, business activity and interaction with other entities in the industry).

After calculating said indicators, their values are translated into points (from 1 to 4 ) depending on the location on the scale of values for other enterprises in the industry [15]. If a value of the indicator tends to the most positive from the point of view of EFS value, the company receives 4 points for this indicator, while the worst values of the indicator get lower points. The weight of factors was determined by the expert method depending on its importance and impact with regards to EFS of an enterprise.

The integrated indicator of rapid assessment of EFS of the enterprise (Ifeb.exp.) is calculated by the formula:

$$
\mathrm{I}_{\text {fes.expr. }}=\sum_{i=1}^{n} F_{i} \times W_{i}
$$

Where $F i-$ a score obtained by an enterprise on certain factor characterized by an indicator $i$ (restriction:

$1 \leq \mathrm{F}_{\mathrm{i}} \geq 4$ ); $W_{i}$ is the weight of the factor $F i$ (restriction: $\left.0<W_{i}<1 ; \sum_{i=1}^{n} w_{i}=1\right) ; n-\quad$ the number of components $F i ; n=10$.
To interpret the results of the assessment of the integrated indicator, the mathematical distribution of the set of points (from 1 to 4 ) in the quartile [16] was used (upper quartile (3.25 points), median (2.5 points), lower quartile (1.75 points). Accordingly, the value of the integrated indicator of financial and economic security of the enterprise is divided into several layers: high - if an obtained value of the integrated indicator is in the area higher than the upper quartile, satisfactory - if an obtained value of the integrated indicator is higher than the median, unsatisfactory - if a value is in the area between the lower quartile and the median, critical - if a value of the integrated indicator is in the area below the lower quartile.

\section{RESULTS OF THE RESEARCH}

The results of the rapid assessment of EFS state at 11 domestic defense enterprises ( 2 enterprises of a private ownership and 9 which are state-owned), which was carried out based on their financial statements (according to available data as of January 1, 2020) and using the analysis [15], are presented in the Table 1.

The results show that with the onset of the military conflict in the Eastern Ukraine, defense companies of a state ownership have significantly strengthened EFS and almost all of the analyzed companies in the dataset received either high or satisfactory scores in 2018-2019. 
Table 1. The scores of the integrated indicator for rapid diagnostics of the state of EFS at Ukraine's defense industry enterprises in 2014-2019

\begin{tabular}{|c|c|c|c|c|c|}
\hline Company & 2014 & 2015 & 2016 & 2017 & 2019 \\
\hline \multicolumn{6}{|c|}{ Companies (private) } \\
\hline FED & 2,3 & 2,4 & 2,7 & 2,5 & 3 \\
\hline $\begin{array}{l}\text { Kuznya na Rybalskomu Plant Private Joint- } \\
\text { Stock Company }\end{array}$ & 1,9 & 1,8 & 1,8 & 2,1 & 2,4 \\
\hline \multicolumn{6}{|c|}{ State-owned Companies (SoE) } \\
\hline \multicolumn{6}{|c|}{ Amored \& automotive equipment cluster } \\
\hline State Company "Kharkiv Armored Plant" & 1,9 & 2,3 & 3,6 & 3 & 3,3 \\
\hline Lviv Armored Plant State Company & 3,6 & 2,7 & 2,4 & 1,7 & 1,4 \\
\hline Kyiv Armored Plant State Company & 3 & 3,2 & 2,2 & 2,6 & 3 \\
\hline State Company "Plant named after Malishev» & 1,6 & 1,5 & 1,3 & 1,8 & 3 \\
\hline Kharkiv Automobile Plant State Company & 1,6 & 1,9 & 3,8 & 2 & 3 \\
\hline \multicolumn{6}{|c|}{ Aircraft construction \& aircraft repair cluster } \\
\hline $\begin{array}{l}\text { State Company "Lviv State Aircraft Repair } \\
\text { Plant" }\end{array}$ & 3,4 & 3,2 & 3 & 3,4 & 3,2 \\
\hline \multicolumn{6}{|c|}{ High-precision weapons \& ammunition cluster } \\
\hline $\begin{array}{l}\text { State Company "State Kyiv Design Bureau" } \\
\text { Luch" }\end{array}$ & 2,5 & 2,9 & 2,9 & 2,7 & 2,7 \\
\hline Joint-Stock Company (SoE) "Artem" & 2,9 & 2 & 2,2 & 2,8 & 2,3 \\
\hline \multicolumn{6}{|c|}{ Radar, radio and air defense cluster } \\
\hline SoE "Lviv Radio Repair Plant" & 3,4 & 3,2 & 3 & 3,4 & 3,2 \\
\hline
\end{tabular}

Source: authors using [15, 17-19]

\section{DISCUSSION OF RESULTS}

In the armored and automotive equipment cluster, the SoE "Lviv Armored Plant" was the exception. EFS of that company during 2014-2019 was at a negative level due to systematic disruptions of the state defense order due to forbidden corruption practices and related shutdowns (seizure of accounts).

In contrast, the situation with EFS at other enterprises of this cluster was the most stable, in particular, at the State Company "Kyiv Armored Plant" and the State Company "Kharkiv Armored Plant", due to their active interaction with the market environment: the enterprise expanded the scope of equipment repair services, and implemented export contracts. Another enterprise that produces armored products in Ukraine is the State Company "Plant named after Malyshev", which in recent years was in crisis due to the mismatch of existing production capacity to the actual volume of product orders. However, due to the implementation of the export contract with Thailand in 2019, the company was able to improve the situation and reached a satisfactory EFS value.
A separate position in the study list is occupied by the SoE "Kharkiv Automobile Plant", the EFS score of which in recent years has fluctuated from critical to high since this company received almost no governmental orders to repair military equipment and had no access to foreign markets, which forced it to work in a competitive environment with private companies in the domestic market for car repairs.

The following group of traditionally stable defense enterprises of a state ownership in recent years includes: SoE "Lviv Radio Repair Plant" (radar, radio communication, and air defense systems cluster) and SoE "Lviv State Aircraft Repair Plant" (aircraft construction and aircraft repair cluster), whose EFS scores varied from satisfactory to high due to, in practice, the monopolistic position of these enterprises in the domestic arms market and active position in the foreign market.

This group of stable companies, from the point of view of financial security, can also include enterprises of the cluster of high-precision weapons and ammunition: SoE Kyiv State Design Bureau "Luch" (EFS score over the past 5 years remains satisfactory), due to organizing 
independent production of defense products of its own design at their R\&D facilities. Most of these products should have been produced at the production facilities of the State Joint-Stock Holding Company "Artem", as this company is a serial manufacturer of high-tech defense products, with which "Luch" is in partnership. This, together with more active activity in foreign markets and solving the problem of import substitution of components, would allow State Joint-Stock Company "Artem" to increase the EFS value to satisfactory (currently, this enterprise is at an unsatisfactory EFS level).

In the recent years "FED", among the private defense companies in the dataset, has demonstrated a satisfactory EFS values, primarily due to the use of broad cooperation in sales, export activities with competitive products.

Another private joint-stock company "Kuznya at Rybalskyy Plant" in 2014-2019 was in a state of crisis due to a weak adaptation to the market changes. The company had a limited range of services it provided. At the same time, after the company successfully participated in the state defense procurement for the production of armored cutters for the Ukrainian Navy, its EFS scores increased, although did not exceed the limits of unsatisfactory level.

\section{CONCLUSIONS}

Rapid assessment of the state of EFS at the Ukrainian defense enterprises in terms of interaction with the business environment has confirmed indirect impact of the use of active interaction with the external stakeholders on the EFS value (by increasing exports/imports contracts with customers, establishing partner relations with suppliers/consumers, government relations, etc.).

Different values of EFS at the analyzed companies are due to their industry specificity, variety of existing business practices, organizational and technological features (in particular, density of cooperation), demand, and current orders of the Armed Forces of Ukraine, state regulations, etc.

Ukraine's private defense companies have demonstrated a positive impact of active participation in the production of defense goods (which is a global trend) on their growth which resulted in better EFS indicators. In addition, there is a dependency of the EFS state of these enterprises with their governance practices and capacity to respond to the external fluctuations and shocks, including those arising through the establishment of result-oriented interactions with external stakeholders and partners.

\section{REFERENCES}

[1] Mohammed Abdullah Al-Hagery, Maryam Abdullah Alzaid, Tahani Soud Alharbi and Moody Abdulrahman Alhanaya (2020), "Data Mining Methods for Detecting the Most Significant Factors Affecting Students' Performance", International
Journal of Information Technology and Computer Science, vol. 12, no. 5, pp. 1-13, DOI: 10.5815/ijitcs.2020.05.01

[2] Bekim Fetaji, Majlinda Fetaji, Mirlinda Ebibi and Samet Kera (2018), "Analyses of Impacting Factors of ICT in Education Management: Case Study", International Journal of Modern Education and Computer Science, vol. 10, no. 2, pp. 26-34, DOI: 10.5815/ijmecs.2018.02.03

[3] Shafat Khan (2019), "Cloud Computing: Issues and risks of Embracing the Cloud in a Business Environment", International Journal of Education and Management Engineering, vol. 9, no. 4, pp. 4456, DOI: 10.5815/ijeme.2019.04.05

[4] Kyrychenko, O.A. Sidak, V.S. and Laptyev, S.M. (2018), Problemy upravlinnya ekonomichnoyu bezpekoyu sub"yektiv hospodaryuvannya [Problems of economic security management of business entities], UEP «Krok», Kyiv, Ukraine.

[5] Theodore Baird (2016), "Who speaks for the European border security industry? A network analysis", European Security, vol. 1, pp. 37-58, available

at: https://www.tandfonline.com/author/Baird\%2C+T heodore

[6] Kozachenko, H.V. and Pohorelov, Yu. S. (2015), "About some problems in modern economic security", Upravlinnya proektamy ta rozvytok vyrobnytstva, vol. 3, pp. 6-18.

[7] Avanesova, N.E. (2017), “A systematic approach to the formation of a strategy for ensuring the economic security of Ukraine's defense industry in the context of European integration". Visnyk ekonomiky transportu $i$ promyslovosti, vol. 57 pp. 20-27.

[8] Artemenko, L.P. (2017), “Development of defense enterprises in the conditions of forced remilitarization of Ukraine's economy", Stratehichni priorytety, vol. 3, pp. 140 - 149.

[9] Momot, T.V. and Avanesova, N.E. (2018), Ekonomichna bezpeka pidpryyemstv oboronnopromyslovoho kompleksu Ukrayiny: teoriya, metodolohiya, praktyka [Economic security of enterprises of the defense-industrial complex of Ukraine: theory, methodology, practice, KHNUMH im. O. M. Beketova, Kharkiv, Ukraine.

[10] Zhyvko, Z.B. (2014), “Analysis of typical approaches to assessing the economic security of the enterprise", Upravlinnya proektamy ta rozvytok vyrobnytstva, vol. 1(49), pp. 124-138.

[11] Zhykhor, O.B. Horokhovats'kyy, V.O. and Oleynikova, A.Yu. (2013), "Calculation of the 
integrated indicator of financial security of the enterprise", Finansovo-kredytna diyal'nist': problemy teoriyi ta praktyky, vol. 2, pp. 66-171.

[12] Korystin, Oleksandr and Svyrydiuk, Nataliia (2021), "Activities of Illegal Weapons Criminal Component of Hybrid Threats", Proceedings of the International Conference on Economics, Law and Education Research (ELER 2021), vol. 170, 22 March, pp. 86-91, DOI: 10.2991/aebmr.k.210320.016

[13] Tkachenko, Volodymyr Kwilinski, Aleksy Korystin, Oleksandr Svyrydiuk, Natalia and Tkachenko, Iryna (2019), “Assessment of information technologies influence on financial security of economy", Journal of security and sustainability issues, march, vol. 8, no. 3, pp. 375385, DOI: $10.9770 /$ jssi.2019.8.3(7)

[14] Ministerstvo ekonomichnoho rozvytku i torhivli Ukrayiny (2014), “Order on Methodical
Recommendations for Calculating the Level of Economic Security of Ukraine", available at: http://www.me.gov.ua/Documents/List?lang=ukUA\&tag=MetodichniRekomendatsii

[15] Ofitsiynyy sayt Analitychnoyi systemy You Control (2020), available at: http://www. youcontrol.com.ua

[16] Knoch, Jessica (2018), "How are Quartiles Used in Statistics?", Magoosh Statistics Blog, available at: https://magoosh.com/statistics/quartiles-usedstatistics

[17] Ofitsiynyy sayt Derzhavnoyi sluzhby statystyky Ukrayiny (2021), available at: http://www.ukrstat.gov.ua

[18] Ofitsiynyy sayt DK "Ukroboronrom" (2021), available at: https://ukroboronprom.com.ua/uk

[19] Ofitsiynyy sayt "Liha oboronnykh pidpryyemstv" (2021), available at: http://ldc.org.ua 